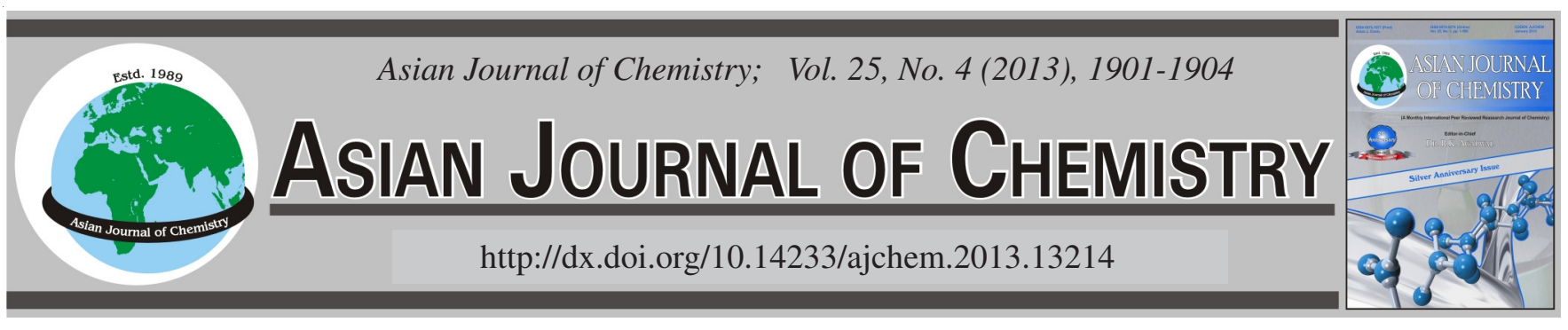

\title{
A Facile Synthesis of Two Brucine-Steroid Derivatives
}

\author{
Lauro Figueroa-Valverde ${ }^{1, *}$, Francisco Díaz-Cedillo² ${ }^{2}$, Elodia Garcia-Cervera ${ }^{1}$, \\ Maria Lopez-Ramos ${ }^{1}$ and Eduardo Pool-Gomez ${ }^{1}$
}

\begin{abstract}
${ }^{1}$ Laboratory of Investigation in Biological Science \& Pharmacochemistry, Facultyof Chemical Biological Sciences, University Autonomic of Campeche, Av. Agustín Melgar, Col Buenavista C.P. 24039 Campeche Cam., México

${ }^{2}$ Escuela Nacional de Ciencias Biológicas del Instituto Politécnico Nacional. Prol. Carpio y Plan de Ayala s/n Col. Santo Tomas, C.P. 11340, México D.F.
\end{abstract}

*Corresponding author: Fax: +52 9818119800 Ext. 73002; Tel: +52 9818119800 Ext. 73006; E-mail: lauro_1999@yahoo.com

\begin{abstract}
In this study, two brucine-steroid derivative were synthesized. In first stage, the brucine-androsterone derivative was development by the reaction of $\mathrm{N}^{1}$-(2,3-dimethoxystrychnidin-10-yliden)-ethane-1,2-diamine and androsteronehemisuccinate using as catalyst a carbodiimide derivative. The second stage was achieved by the reaction of $\mathrm{N}^{1}$-(2,3-dimethoxystrychnidin-10-yliden)-ethane-1,2-diamine with $\beta$-estradiol 17-hemisuccinate to form the brucine-estradiol conjugatein presence of a carbodiimide derivative.In conclusion, in this study we show a facile procedure for synthesis of two brucine-steroid derivatives.

Key Words: Brucine, Androsterone, 17- $\beta$-Estradiol, Carbodiimide.
\end{abstract}

\section{INTRODUCTION}

There are studies which show that several derivatives of brucine have been developed for its use in different biological and analytical methods $\mathrm{s}^{1-4}$. For example, a report shows the synthesis of N-chloromethylbrucine chloride by the reaction of brucine with dichloromethane ${ }^{5}$. Other studies have shown the preparation of a brucine derivative (brucidine) by electrolytic reduction of brucine ${ }^{6}$. In addition, there are reports of the synthesis of $\mathrm{N}$-(5-carboxypentyl)brucinium bromide via $\mathrm{N}$-alkylation of brucine with 6-bromohexanoic acid ${ }^{7}$. Other experimental data showed the preparation of compounds brucinium hydrogen (S)-malate pentahydrate and anhydrous brucinium hydrogen (2R,3R)-tartrate by the reaction between brucine and D-L-malic acid or L-tartaric acid in ethanol:water ${ }^{8}$. Additionally, the porphyrin-brucine conjugates was synthetized by the N-alkylation of brucine with alkylbromotetraphenylporphyrin derivatives ${ }^{9}$.

Recently, a brucine derivative $\left(\mathrm{N}^{1}-(2,3\right.$-dimethoxy strychnidin-10-yliden)-ethane-1,2-diamine) was synthetized by the reaction of brucine and ethylenediamine using boric acid as catalyst. Also other brucine derivative (11-[(2-aminoethylamino)-methyl]-2,3-dimethoxystrychnidin-10-ona) was prepared by the reaction of brucine with ethylenediamine in presence of formaldehyde ${ }^{10}$. Additionally, other study showed the synthesis of a brucine-dihydropirymidine derivative using the multi-component system (brucine, benzaldehyde and thiourea $)^{11}$. All these experimental data show several procedures for synthesis of brucine derivatives; nevertheless, expensive reagents and special conditions are required. Therefore, in this study two new brucine-steroid derivatives were synthetized using a carbodiimide as catalyst.

\section{EXPERIMENTAL}

The compounds $\mathrm{N}^{1}$-(2,3-dimethoxystrychnidin-10-yliden)ethane-1,2-diamine (1) and androsteron-ehemisuccinate (2) were prepared according to a previously reported method of Figueroa $^{10,12}$. The other compounds evaluated in this study were purchased from Sigma-Aldrich Co. Ltd. The melting points for the different compounds were determined on an Electrothermal (900 model). Infrared spectra (IR) were recorded using $\mathrm{KBr}$ pellets on a Perkin Elmer Lambda 40 spectrometer. ${ }^{1} \mathrm{H}$ and ${ }^{13} \mathrm{C}$ NMR spectra were recorded on a Varian VXR-300/5 FT NMR spectrometer at 300 and $75.4 \mathrm{MHz}$ in $\mathrm{CDCl}_{3}$ using TMS as internal standard. EIMS spectra were obtained with a Finnigan Trace GCPolaris Q. spectrometer. Elementary analysis data were acquired from a Perkin Elmer Ser. II CHNS/0 2400 elemental analyzer.

N-[2-(2,3-Dimethoxystrychnidin-10-ylideneamino)ethyl]-succinamic acid 10,13-dimethyl-17-oxo-hexadecahydrocyclopenta[a]phenanthren-3-yl ester (3): A solution of 1 (200 mg, $0.25 \mathrm{mmol}), 2$ (96 mg, $0.25 \mathrm{mmol}), \mathrm{N}-(3-$ dimethylaminopropyl)-N'-ethylcarbodiimide (78 mg, 0.50 
$\mathrm{mmol}$ ) in $10 \mathrm{~mL}$ of methanol was stirring for $72 \mathrm{~h}$ to room temperature. The reaction mixture was evaporated to a smaller volume. After the mixture was diluted with water and extracted with chloroform. The organic phase was evaporated to dryness under reduced pressure, the residue was purified by crystallization from methanol:water (3:1) yielding $45 \%$ of product, m.p. $120-122^{\circ} \mathrm{C}$; IR (KBr, $\left.v_{\max }, \mathrm{cm}^{-1}\right)$ : 3320, 2832, 1738, 1710 , 1640; ${ }^{1} \mathrm{H}$ NMR $\left(300 \mathrm{MHz}, \mathrm{CDCL}_{3}\right) \delta_{\mathrm{H}}: 0.84(\mathrm{~s}, 3 \mathrm{H}), 0.86(\mathrm{~s}$, $3 \mathrm{H}), 0.90-1.04$ (m, 2H), 1.19-1.31 (m, 6H), $1.36(\mathrm{~m}, 1 \mathrm{H}), 1.39$ $1.43(\mathrm{~m}, 2 \mathrm{H}), 1.46(\mathrm{~m}, 1 \mathrm{H}), 1.51-1.63(\mathrm{~m}, 4 \mathrm{H}), 1.64(\mathrm{~m}, 1 \mathrm{H})$, $1.65(\mathrm{~m}, 1 \mathrm{H}), 1.68(\mathrm{~m}, 1 \mathrm{H}), 1.70(\mathrm{~m}, 1 \mathrm{H}), 1.72-1.77(\mathrm{~m}, 2 \mathrm{H})$, $1.78-1.80(\mathrm{~m}, 2 \mathrm{H}), 1.84-1.90$ (m, 2H), 1.94-1.98 (m, 2H), 2.10$2.23(\mathrm{~m}, 2 \mathrm{H}), 2.30-2.36(\mathrm{~m}, 2 \mathrm{H}), 2.38(\mathrm{~m}, 1 \mathrm{H}), 2.42(\mathrm{t}, 2 \mathrm{H}$, $J=6.7 \mathrm{~Hz}), 2.47(\mathrm{~m}, 1 \mathrm{H}), 2.50(\mathrm{~m}, 1 \mathrm{H}), 2.54(\mathrm{t}, 2 \mathrm{H}, J=6.7$ $\mathrm{Hz}), 2.71-2.92(\mathrm{~m}, 3 \mathrm{H}), 3.38(\mathrm{t}, 2 \mathrm{H}, J=6.7 \mathrm{~Hz}), 3.37-3.62$ $(\mathrm{m}, 4 \mathrm{H}), 3.74(\mathrm{t}, 2 \mathrm{H}, J=6.7 \mathrm{~Hz}), 3.80(\mathrm{~s}, 3 \mathrm{H}), 3.90(\mathrm{~s}, 3 \mathrm{H})$, $4.11(\mathrm{~m}, 1 \mathrm{H}), 4.78(\mathrm{~m}, 1 \mathrm{H}), 5.88(\mathrm{~m}, 1 \mathrm{H}), 6.88(\mathrm{~s}, 1 \mathrm{H}), 7.83$ (s, 1H), 8.02 (broad, $1 \mathrm{H}) \mathrm{ppm} .{ }^{13} \mathrm{C} \mathrm{NMR}\left(75.4 \mathrm{~Hz}, \mathrm{CDCl}_{3}\right) \delta_{\mathrm{C}}$ : 13.74 (C-59), 15.36 (C-57), 20.08 (C-52), 21.61 (C-47), 27.79 (C-41), 28.02 (C-55), 28.06 (C-56), 28.12 (C-13), 29.22 (C-36), 29.44 (C-4), 30.22 (C-17), 31.55 (C-51), 31.95 (C-35), 32.04 (C-3), 32.22 (C-16), 35.11 (C-45), 35.25 (C-43), 35.38 (C-42), 35.70 (C-48), 35.90 (C-53), 39.94 (C-8), 40.40 (C-15), 40.58 (C-27), 42.13 (C-54), 45.68 (C-9), 47.67 (C-50), 48.64 (C-44), 50.70 (C-26), 51.34 (C-46), 52.24 (C-7), 56.11 (C-34), 56.72 (C-32), 56.86 (C-5), 64.62 (C-18), 65.08 (C-10), 68.60 (C-2), 75.01 (C-40), 79.30 (C-14), 98.45 (C-21), 105.73 (C-24), 127.85 (C-19), 139.15 (C-20), 143.26 (C-23), 147.83 (C-22), 148.01(C-12), 169.82 (C-29), 172.34 (C-37), 221.02 (C-49) ppm. EI-MS m/z: $810.38\left(\mathrm{M}^{+} \mathrm{I}\right), 778.01$, 189.21. Anal. calcd. (\%) for $\mathrm{C}_{48} \mathrm{H}_{66} \mathrm{~N}_{4} \mathrm{O}_{7}$ : C, 71.08; H, 8.20; N, 6.91; O, 13.81. Found (\%): C, 71.02; H, 8.22.

N -[2-(2,3-Dimethoxystrychnidin-10-ylideneamino)ethyl]-succinamic acid 3-hydroxy-13-methyl-7,8,9,11,12,13, 14,15,16,17-decahydro-6H-cyclopenta[a]phenanthren-17yl ester (5): A solution of $\mathbf{1}$ (200 mg, $0.25 \mathrm{mmol}$ ), $\beta$-estradiol 17-hemisuccinate (93 mg, $0.25 \mathrm{mmol}$ ), N-(3-dimethylaminopropyl)-N'-ethylcarbodiimide (78 $\mathrm{mg}, 0.50 \mathrm{mmol})$ in $10 \mathrm{~mL}$ of methanol was stirring for $72 \mathrm{~h}$ to room temperature. The reaction mixture was evaporated to a smaller volume. After the mixture was diluted with water and extracted with chloroform. The organic phase was evaporated to dryness under reduced pressure, the residue was purified by crystallization from methanol:water (3:1) yielding $60 \%$ of product, m.p. 182$184{ }^{\circ} \mathrm{C}$; IR (KBr, $\left.v_{\max }, \mathrm{cm}^{-1}\right): 3338,3320,2832,1738,, 1640$; ${ }^{1} \mathrm{H}$ NMR $\left(300 \mathrm{MHz}, \mathrm{CDCl}_{3}\right) \delta_{\mathrm{H}}: 0.82(\mathrm{~s}, 3 \mathrm{H}), 0.97-1.20(\mathrm{~m}$, $3 \mathrm{H}), 1.34(\mathrm{~m}, 1 \mathrm{H}), 1.43-1.501 .51(\mathrm{~m}, 1 \mathrm{H}), 1.53-1.65(\mathrm{~m}, 2 \mathrm{H})$, $1.66-1.69(\mathrm{~m}, 2 \mathrm{H}), 1.72-1.73(\mathrm{~m}, 2 \mathrm{H}), 1.77-1.91$ (m, 4H), 192$196(\mathrm{~m}, 2 \mathrm{H}), 2.14(\mathrm{~m}, 1 \mathrm{H}), 2.15-2.20(\mathrm{~m}, 2 \mathrm{H}), 2.28(\mathrm{~m}, 1 \mathrm{H})$, $2.42(\mathrm{t}, 2 \mathrm{H}, J=6.7 \mathrm{~Hz}), 2.48(\mathrm{~m}, 1 \mathrm{H}), 2.52(\mathrm{t}, 2 \mathrm{H}, J=6.7 \mathrm{~Hz})$, $2.55(\mathrm{~m}, 1 \mathrm{H}), 2.67(\mathrm{~m}, 1 \mathrm{H}), 2.69(\mathrm{~m}, 1 \mathrm{H}), 2.74-3.40(\mathrm{~m}, 5 \mathrm{H})$, $345(\mathrm{t}, 2 \mathrm{H}, J=6.7 \mathrm{~Hz}), 3.48(\mathrm{~m}, 1 \mathrm{H}), 3.56(\mathrm{t}, 2 \mathrm{H}, J=6.7 \mathrm{~Hz})$, 3.58-3.67 (m, 2H),3.83 (s, 3H), $4.01(\mathrm{~s}, 3 \mathrm{H}), 4.60(\mathrm{~m}, 1 \mathrm{H})$, $4.73(\mathrm{~d}, 1 \mathrm{H}), 5.88(\mathrm{~m}, 1 \mathrm{H}), 6.71(\mathrm{~d}, 1 \mathrm{H}), 6.75(\mathrm{~d}, 1 \mathrm{H}), 7.28(\mathrm{~d}$, $1 \mathrm{H}), 7.51$ (s, 1H), 8.22 (broad, $2 \mathrm{H}) \mathrm{ppm} .{ }^{13} \mathrm{C} \mathrm{NMR}(75.4 \mathrm{~Hz}$, $\left.\mathrm{CDCl}_{3}\right) \delta_{\mathrm{C}}: 13.04(\mathrm{C}-57), 23.64(\mathrm{C}-48), 26.78(\mathrm{C}-45), 26.85$ (C-49), 27.40 (C-47), 28.10 (C-13), 29.57 (C-35), 29.68 (C-4), 30.11(C-36), 30.20 (C-50), 30.80 (C-17), 31.95 (C-3),
32.44 (C-16), 34.12 (C-27), 37.30 (C-46), 38.83 (C-8), 40.02 (C-43), 40.82 (C-15), 44.23 (C-41), 44.35 (C-44), 45.82 (C-9), 50.18 (C-42),50.60 (C-26), 54.01(C-7), 55.76 (C-34), 55.89 (C-32), 57.09 (C-5), 64.82 (C-18), 65.30 (C-10), 68.60 (C-2), 80.57 (C-14) , 81.12 (C-40), 98.40 (C-21), 108.73 (C-24), 110.33 (C-54), 118.89 (C-56), 126.98 (C-53), 127.95 (C-19), 137.67 (C-52), 138.34 (C-51), 138.65 (C-20), 141.36(C-23), 145.67 (C-22), 148.07 (C-12), 148.38 (C-55), 169.91 (C-29), 172.24 (C-37) ppm. EI-MS m/z: $792.40\left(\mathrm{M}^{+}\right.$ I), 519.27, 587.73. Anal. calcd. (\%) for $\mathrm{C}_{47} \mathrm{H}_{60} \mathrm{~N}_{4} \mathrm{O}_{7}$ : C, 71.19; H, 7.63; N, 7.07; O, 14.12. Found (\%): C, 71.10; H, 7.60.

\section{RESULTS AND DISCUSSION}

In this study, two brucine-steroid derivative were synthesized; in first stage, was achieved by reacting $\mathrm{N}^{1}$-(2,3-dimethoxystrychnidin-10-yliden)-ethane-1,2-diamine (1) with androsteronehemisuccinate (2) resulting in amide bond formation involved in the compound $\mathbf{3}$ (Fig. 1). It is important to mention that although many procedures for the formation of amides are known in the literature, the most widely used employs carboxylic acid chlorides as the electrophiles which react with the amino group in the presence of an acid scavenger ${ }^{13}$. Despite its wide scope, this protocol suffers from several drawbacks: most notable are the limited stability of many acid chlorides and the need for hazardous reagents for their preparation (e.g., thionyl chloride $)^{14}$. Therefore, in this study $\mathrm{N}$-(3-dimethylaminopropyl)-N'-ethylcarbodiimide (EDC) ${ }^{15}$ was used to form compound $\mathbf{3}$.

The results of ${ }^{1} \mathrm{H}$ NMR spectrum of $\mathbf{3}$ shows signals at 0.84 and $0.86 \mathrm{ppm}$ for methyl of steroid nucleus; at 0.90-1.31, 1.39-1.43, 1.51-1.63, 1.68, 1.70, 1.78-1.80, 1.94-1.98, 2.38, 2.47 and $4.78 \mathrm{ppm}$ for steroid nucleus; at 1.36, 1.46, 1.65, $1.68,1.72-1.77,1.84-1.90,2.10-2.23,2.50,2.71-2.92,4.11$, 5.88 and 7.83 ppm for brucine nucleus. Other signals at 2.42 and $2.54 \mathrm{ppm}$ for methylenes bound to both amide and ester groups; at 3.38 and $3.74 \mathrm{ppm}$ for methylenes bound to imino and amino groups; at 3.80 and 3.90 ppm for methoxy groups were found. Finally, a signal at 8.02 for proton of amide group was found. It is important to mention that the ${ }^{1} \mathrm{H}$ NMR spectra of the secondary amides are usually more complex than the primary amides due to the presence of a substituent bonded to the amide nitrogen atom. These substituents produce a much wider range of chemical shifts for the amide proton which may, in addition, display coupling to aliphatic groups bonded to it. The chemical shifts of aliphatic groups bonded to the carbonyl group are similar to those observed for the primary amides, while those groups bonded to the nitrogen resonate at slightly lower field than the corresponding amines ${ }^{16}$.

Other data indicate that ${ }^{13} \mathrm{C}$ NMR spectrum contains peaks of chemical shifts at 13.74 and $15.36 \mathrm{ppm}$ for methyl groups involved in the steroid fragment; at 20.08-28.06, 31.55, 35.11$35.90,42.13,47.67-48.64,51.34$ and $75.01 \mathrm{ppm}$ for steroid nucleus; at 28.12, 29.44-30.22, 32.04-32.22, 39.94-40.40, $45.68,52.24,56.86-68.60$ and 79.30-148.01 ppm for brucine nucleus; at 29.22 and 31.95 ppm for methylenes bound to both amide and ester groups; at 40.58 and $50.70 \mathrm{ppm}$ for carbons bound to both imino and amino groups. Finally, other signals at 56.11 and $56.72 \mathrm{ppm}$ for methoxy groups; at 169.82 for 


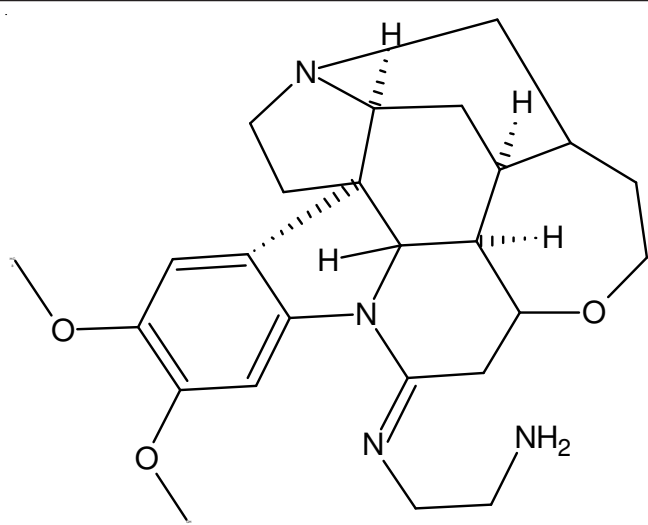<smiles>C[C@]12CCC3C(CCC4CC(OC(=O)CCC(=O)O)CC[C@@]43C)C1CCC2=O</smiles>

2

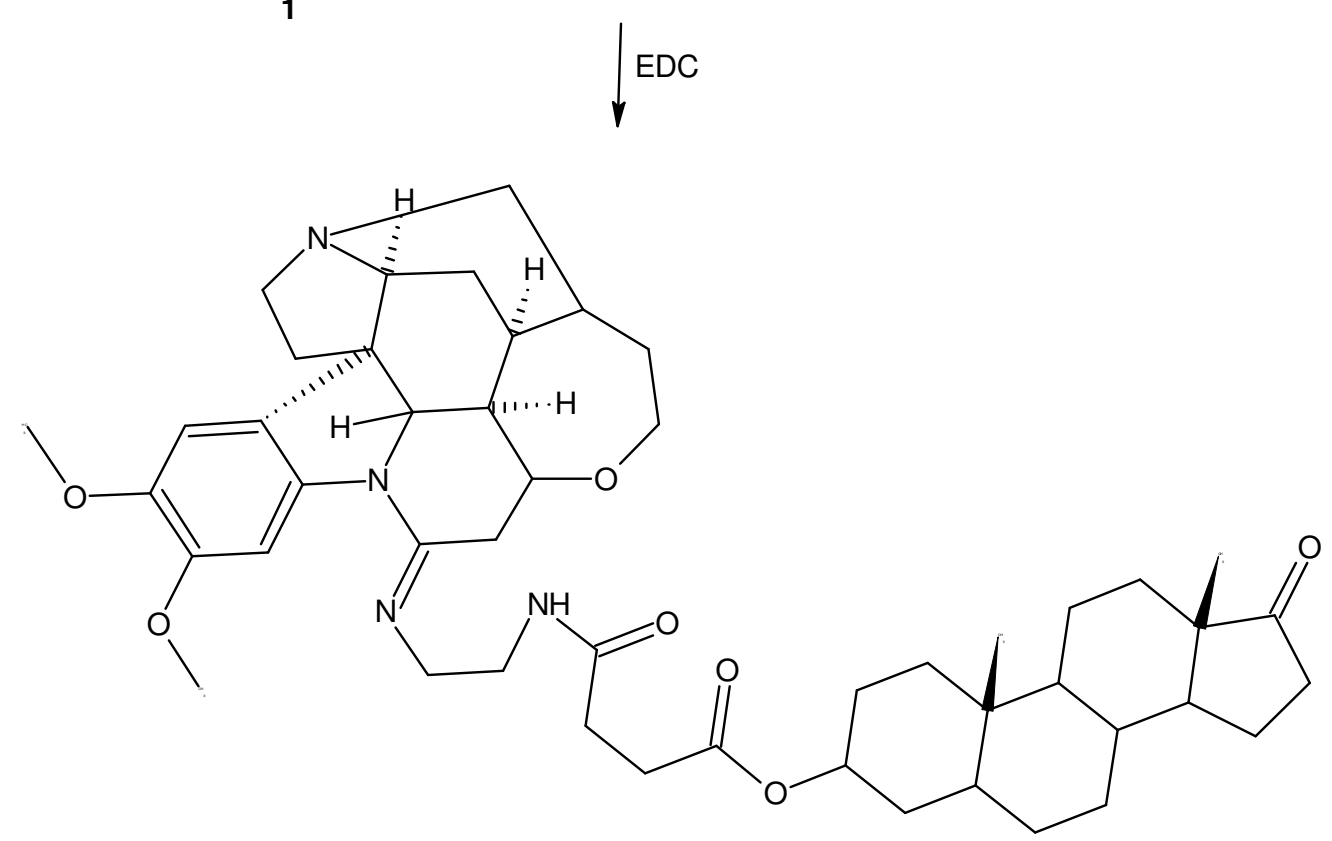

3

Fig. 1. Synthesis of N-[2-(2, 3-dimethoxystrychnidin-10-ylideneamino)-ethyl]-succinamic acid 10,13-dimethyl-17-oxo-hexadecahydrocyclopenta[a]phenanthren-3-yl ester (3). Reaction between $\mathrm{N}^{1}$-(2,3-dimethoxystrychnidin-10-yliden)-ethane-1,2-diamine (1) and androsteronehemisuccinate (2) using a carbodiimide derivative (EDC) as catalyst

amide group; at 172.34 for ester group and at 221.02 for ketone group were found. In addition, the presence of $\mathbf{3}$ was further confirmed from mass spectrum which showed a molecular ion at $\mathrm{m} / \mathrm{z} 810.38$.

The second step was achieved by the reaction of 1 with $\beta$-estradiol-17-hemisuccinate (4) to form an amide group involved in compound 5 (Fig. 2) using the same method for the synthesis of $\mathbf{3}$. The ${ }^{1} \mathrm{H}$ NMR spectrum of $\mathbf{5}$ showed signals at $0.82 \mathrm{ppm}$ for methyl group involved in the steroid fragment; at $0.97-1.20,1.43-1.50,1.53-1.65,1.72-1.73,1.92-1.96$ and $2.15-2.20,2.55,2.69,4.60$ and $6.71-7.28 \mathrm{ppm}$ for steroid nucleus; at $1.34,1.51,1.66-1.69,1.77-1.91,2.14-2.28$ 2.48, $2.67,2.74-3.40,3.48,3.58-3.67,4.73-5.88$ and $7.51 \mathrm{ppm}$ for brucine nucleus. Other signals at 2.42 and $2.52 \mathrm{ppm}$ for methylene groups bound to both amide and ester groups; at 3.45 and $3.56 \mathrm{ppm}$ for methylene groups bound to both imino and amino groups; at 3.83 and 4.01 ppm for methoxy groups; at $8.22 \mathrm{ppm}$ for both hydroxyl and amide group were found.
On the other hand, the ${ }^{13} \mathrm{C}$ NMR spectrum of 5 contains peaks of chemical shifts at 13.04 ppm for methyl group involved in the steroid fragment; at 23.64-27.40, 50.20, 37.30, 40.43 , 44.23-44.35, 50.18, 81.12, 110.33-126.58, 137.67138.34 and $148.38 \mathrm{ppm}$ for steroid nucleus; at 28.10, 29.68, $30.80,32.44,38.83,40.82,45.82$, 54.01, 57.09-80.57, 98.44$108.73,127.95$ and $138.65-148.07$ ppm for brucine nucleus. Finally, several signals at 29.57 and $30.11 \mathrm{ppm}$ for methylenes bound to both amide and ester groups; at 34.12 and 50.60 ppm for carbons bound to both imino and amino groups; at 55.76 and 55.89 ppm for methoxy groups; at $169.91 \mathrm{ppm}$ for amide group; at 172.24 for ester group were found. The presence of $\mathbf{5}$ was further confirmed from mass spectrum which showed a molecular ion at $\mathrm{m} / \mathrm{z} 792.40$.

\section{Conclusion}

In this study we show a facile procedure for formation of two brucine-derivatives. 

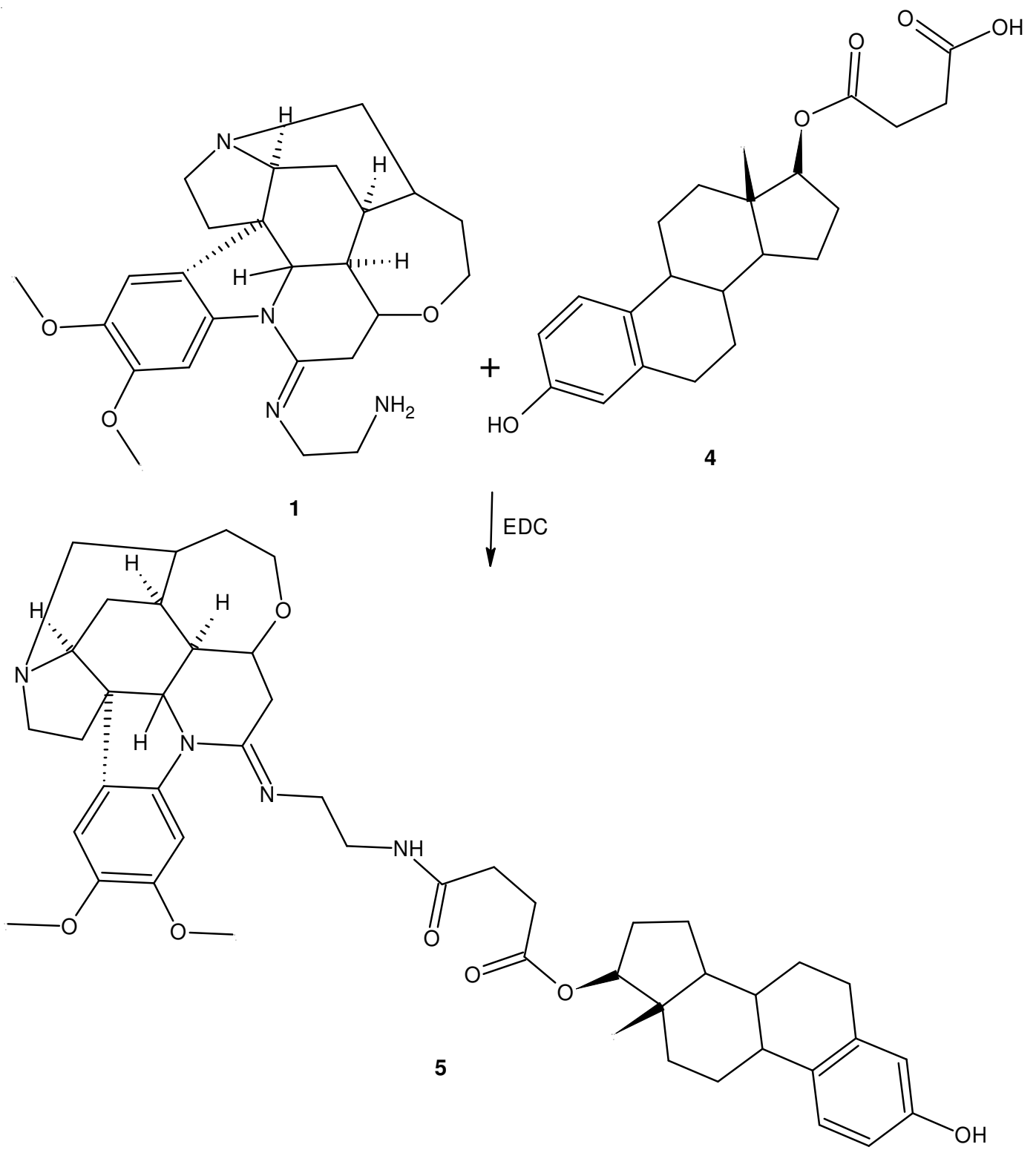

Fig. 2. Synthesis of N-[2-(2,3-dimethoxystrychnidin-10-ylideneamino)-ethyl]-succinamic acid 3-hydroxy-13-methyl-7,8,9,11,12,13,14, 15,16,17-decahydro$6 H$-cyclo- penta[a]phenanthren-17-yl ester (5). Reaction between $\mathrm{N}^{1}$-(2,3-dimethoxystrychnidin-10-yliden)-ethane-1,2-diamine (1) and $\beta$-estradiol 17-hemisuccinate (4) using a carbodiimide derivative (EDC) as catalyst

\section{REFERENCES}

1. K. Zahn, N. Eckstein, C. Tränkle, W. Sadée and K. Mohr, J. Pharm. Exp. Ter., 301, 2720 (2002).

2. A. Black and P. Vogel, Helv. Chim Acta, 67, 1612 (1984).

3. H.Y. Kim, H.-J. Shih, W.E. Knabe and K.S. Oh, Angew. Chem., 121, 7556 (2009).

4. J. Show and T. Hooker, Can. J. Chem., 56, 1222 (1978).

5. N. Birdsall, T. Farries, P. Gharagozloo, S. Kobayashi, S. Lazareno and M. Sugimoto, Mol. Pharm., 55, 778 (1999).

6. S. Findlay, J. Am. Chem. Soc., 73, 3008 (1951)

7. K. Záruba and V. Král, Tetrahedron Asym., 13, 2567 (2002).

8. S. Graham, U. Wemuth and J. White, Acta Cryst., C62, o353 (2006).

9. K. Záruba, J. Králová, Pa. Rezanka, P. Poucková, L. Veverková and V. Král, Org. Biomol. Chem., 8, 3202 (2010).
10. L. Figueroa-Valverde, F. Díaz-Cedillo, M. López-Ramos, E. GarcíaCervera and E. Pool Gómez, Asian J. Chem., 25, 1405 (2013).

11. L. Figueroa-Valverde, F. Díaz-Cedillo, M. López-Ramos, E. GarcíaCervera, E. Pool Gómez and R. Torres-Cutz, Asian J. Chem., 242321 (2012) .

12. L. Figueroa, F. Díaz, A. Camacho, E. Díaz and M. Marvin, Biomédica, 29, 625 (2009).

13. A. Medvedeva, M. Andreev, L. Safronova and G. Sarapulova, Arkivoc, 143 (2001)

14. D. Levin, Org. Process. Res. Dev., 1, 182 (1997).

15. N. DeSilva, Am. J. Respir. Cell. Mol. Biol., 29, 757 (2003).

16. L. Figueroa-Valverde, F. Díaz-Cedillo, L. Tolosa, G. Maldonado and G. Ceballos-Reyes, J. Mex. Chem. Soc., 50, 42 (2006). 